\title{
Comparative Analysis of Conventional and Sharia Food and Beverages Company's Stocks Performance Companies Towards IHSG
}

\author{
Siti Azizziah Azzahra Pernama Putri ${ }^{1}$, Yadi Nurhayadi ${ }^{2}$, Daram Heriansyah ${ }^{3}$ \\ \{azizziahzahra@gmail.com¹, yadinurhayadi@uhamka.ac.id²,daram@uhamka.ac.id ${ }^{3}$ \} \\ University of Muhammadiyah Prof. DR. HAMKA ${ }^{1,2,3}$
}

\begin{abstract}
This research is aimed to determine how the relationship between conventional and sharia stock performance of food and beverages companies with Composite Stock Price Index (IHSG) and then comparison that stock performance of both companies whom listed in Indonesia Stock Exchange (BEI) and Indonesian Sharia Stock Index (ISSI) during 2015-2019. The result of this research is the conventional stock performance hasn't a significant effect while the sharia stock performance has a significant positive effect on IHSG. The result of multiple linear regression analysis, conventional stock performance is inversely proportional or negatively while sharia stock performance is directly proportional or positively affected by return of IHSG. Then the calculation of return showed that sharia food and beverage companies has a better performance than conventional food and beverage companies. The value of risk adjusted performance showed that sharia's food and beverage companies have a lower level of risk which means more guarantees of investment securities. On independent sample t test showed a result there's no significant difference between conventional and sharia's food and beverages of stocks performance.
\end{abstract}

Keywords: Stocks Performance, Stock Return, Sharpe Index, Treynor Index, Jensen Index, IHSG, ISSI.

\section{Introduction}

Investment can be said as the placement of a contract of some wealth or funds owned by investors at this time who intend to get benefits in the future [1]. At this time, investment selection is not only with investments in conventional companies. Indonesian investors are now given more choices to invest or invest, with the launch of the Jakarta Islamic Index (JII) and the Indonesian Sharia Stock Index (ISSI) by the Indonesia Stock Exchange (IDX).

The Indonesia Stock Exchange (IDX) launched a new index based on Islamic law in Indonesia, the Indonesian Sharia Stock Index (ISSI) which coincided on May 12, 2011, with the launch of the index it can be said that there was a lively development on the sharia capital market in Indonesia. The constituents of the Indonesian Sharia Stock Index (ISSI) are all shares listed on the Sharia Stock List and have been listed on the Indonesia Stock Exchange. The constituents of the Indonesian Sharia Stock Index registered and recorded were 437 shares at the time of writing this research. The review of all shares listed on ISSI is carried out every six months (May and November) and will be announced at the beginning of each month and 
the following [2]. Adjustment activities will also always be carried out by ISSI constituents if there are new sharia shares that are recorded or deleted from the List of Sharia Securities.

With the many investment choices, investors are required to better understand the performance of each stock itself. Stock performance means an assessment of how well money management achieves a balance between high returns and acceptable risk The main issues related to stock performance are, (1) stock portfolio returns that have been formed are able to provide returns that exceed (above) other stock portfolio returns that are used as benchmarks (benchmarks) and (2) the returns obtained are in accordance with the level of risk that must be certified. In looking at the performance of a portfolio must also understand several factors, (1) the level of risk, (2) the time period, (3) the use of the benchmark and (4) the investment objectives. Neglecting these factors can result in inappropriate stock performance results which can lead to decisions that are detrimental to investors. Therefore, investors must really understand aspects of the performance of the stock itself in order to be able to make good investment choices.

The growth of the stock market in Indonesia can be observed through the large volume of transactions and the growth of the Composite Stock Price Index (CSPI) on the stock exchange, where the CSPI describes the overall activity in the capital market. If the Jakarta Composite Index (JCI) has increased, the capital market conditions at that time were strengthening. Otherwise, if the CSPI has decreased then it can be said that the condition of the capital market at that time was weakening. Therefore, investors must be able to understand the pattern of stock price developments.

Based on the background above, the objective of this study is to analyze the stock's performance of conventional and sharia food and beverage companies by looking at each company's stock performance by measure stock returns to see whether these factors affect the JCI and then be compared to stock performance with risk adjusted performances. Based on the background of problems that have been described above, then this research problems to be answered from this study are as follows: (1) Does conventional stock performances on food and beverages companies has an effect on composite stock price index? (2) Does sharia stock performances on food and beverages companies has an effect on composite stock price index? (3) Does conventional and sharia stock performances on food and beverages companies has an effect on composite stock price index? (4) Does conventional and sharia stock performances on food and beverages companies has a different significant on each other? From the background that has been described above, the dimension of the research problems were in wide scope, which includes all of stock's food and beverages companies indexed conventional and sharia.

\section{Literature Review}

\subsection{Stock Performance}

One of the most popular financial instruments and is widely chosen by the public is stocks because they can provide attractive benefits. Stock investment can be done in the short or long term according to the wishes of the investors. Investors who choose short-term investments are usually traders. Traders themselves are individuals or companies that carry out trading activities of shares as a source of income. Meanwhile, investors who choose long-term investments generally buy shares to be kept for less than one year. Long-term investors expect 
the company to always develop so that it will get satisfactory benefits from the investment activity.

Both short-term and long-term investors must be able to assess the satisfactory return on investment performance. The company's performance can be seen from the performance of the company's shares by using the value of shares circulating in the capital market. Stock performance will be assessed based on two main issues, namely seeing whether stock returns are able to provide returns that exceed other stock returns that are used as benchmarks and seeing whether stock returns are in accordance with the level of risk borne.

\subsection{Composite Stock Price Index}

The Composite Stock Price Index (IHSG) is a trend of the stock price index numbers that have been calculated and compiled so that it can be used to make comparisons of changes in stock prices at any time. The Composite Stock Price Index also illustrates how the development of stock prices on the stock exchange will be the basis for the development of all activities in the capital market. The investment activities carried out by investors will affect the development of the JCI in the capital market. If there is an increase in the benefit value of the JCI, it will also increase the interest of investors to increase their investment in companies that are listed on the Indonesian stock exchange. The Composite Stock Price Index was officially introduced on April 1, 1983 as an indicator of the price movements of all shares listed on the Indonesia Stock Exchange, both preferred and common shares. On August 10, 1982, there were 13 listed issuers with an index calculation value of 100. Currently, there are 680 issuers listed on the Indonesia Stock Exchange (IDX).

\subsection{Stock's Performance Evaluation}

Evaluating portfolio performance only based on the average return is not very comprehensive, there must be adjusted for risk before they can be compared meaningfully [3]. There are several methods which already involved risk and return in their calculation, such as: Sharpe's measure (1966), Treynor's measure (1966), Jensen's measure (1968).

a) Sharpe's Measeure

Sharpe measure is used to measure how much additional investment returns are obtained for each unit of risk taken. This measure can also be used to view portfolio performance ratings. The high Sharpe index level indicates that the good performance of a company's portfolio. To measure portfolio performance with the Sharpe measurement can use the following formulations:

$$
S p=\frac{\left(R_{i}-R_{f}\right)}{\sigma p}
$$

Sp $\quad=$ Sharpe Measure

$\mathrm{R}_{\mathrm{i}} \quad=$ The security return $\mathrm{i}$ in the observation period

$\mathrm{R}_{\mathrm{f}} \quad=$ Return risk-free rate in the observation period

$\sigma \mathrm{p}=$ Standard deviation or total risk in the observation period 
b) Treynor's Measure

Treynor measurement or often called the reward-to-volatility ratio was developed by Jack Treynor. Similar to the Sharp's measure, the Treynor's measure is used to see portfolio performance by linking stock returns with the amount of risk but with a benchmark for systematic risk (measured by beta). Basically, the calculation of the Treynor's measure is the same as the calculation of the Sharpe's measure, it only changes the risk measured using the standard deviation of the Sharpe's measure to be replaced with stock beta. The higher the Treynor's measure level a stock has, it means that the stock's performance will be relatively better compared to stocks that have a lower Treynor's measure. Calculating the Treynor's measure can use the following formulations:

$$
T=\frac{R_{i}-R_{f}}{\beta}
$$

$$
\begin{array}{ll}
\mathrm{T} & =\text { Treynor's measure } \\
\mathrm{R}_{\mathrm{i}} & =\text { The security return } \mathrm{i} \text { in the observation period } \\
\mathrm{R}_{\mathrm{f}} & =\text { Return risk-free rate in the observation period } \\
\beta & =\text { beta security }
\end{array}
$$

c) Jensen's Measure

Jensen's measure is an measure that shows the difference between the actual rate of return obtained by the stock and the expected rate of return if the stock is on the securities market line. The similarity between the Jensen's measure and the Treynor's measure is in making equations using the benchmark for the securities market line. Whereas the difference between the two is that the Treynor's measure is the same as the slope of the line that connects the risk-free return position to the stock, while the Jensen's measure is the difference between stock returns and market returns. Therefore, the Jensen's measure value may be greater (positive), smaller (negative) or equal (zero). Calculating the Jensen's measure can use the following formulations:

$$
\hat{\mathrm{J}}=\mathrm{R}_{\mathrm{i}}-\left[\mathrm{R}_{\mathrm{f}}+\left(\mathrm{R}_{\mathrm{m}}-\mathrm{R}_{\mathrm{f}}\right) \beta\right]
$$

$$
\begin{array}{ll}
\hat{J} & =\text { Jensen's measure } \\
\mathrm{R}_{\mathrm{i}} & =\text { The security return i in the observation period } \\
\mathrm{R}_{\mathrm{f}} & =\text { Return risk-free rate in the observation period } \\
\mathrm{R}_{\mathrm{m}} & =\text { Return market } \\
\beta & \quad \text { beta security }
\end{array}
$$

\subsection{Hypothesis Development}

In a study entitled "Comparative Analysis of Performance of Sharia Shares and Conventional Shares in Optimal Portfolios with the Single Index Model Approach (Case Study on the Indonesia Stock Exchange in 2013-2015)" said that there were the difference between the performance of Islamic stocks and conventional stocks in each trial evaluation using the single index model approach and also risk adjusted performance [4].

In a study entitled "Strong Correlations of Sharia Market to Conventional Market: Evidence from Indonesia Stock Exchange" said that the CSPI and LQ45 partially or simultaneously had a strong positive correlation to JII or ISSI. These results lead to the 
conclusion that between the Islamic market and conventional markets are still strongly correlated [5].

In a journal entitled "Comparison of Sharia Stock Index Performance with Conventional Indexes for the 2011-2016 Period (Case Study on Indonesian Sharia Stock Indexes and Composite Stock Price Index)". Released in 2017 it concluded that the ISSI index and the IHSG index in the period 2011 to 2016 as measured by the Sharpe method, the ISSI index showed better performance compared to the JCI index [2].

In a journal entitled "Optimization of Stock Value Portfolios: Comparative Study of Sharia and Non-Sharia Stock Performance" concluded that the performance of the stock portfolio between the LQ45 index and JII as a whole didn't have a significant difference. This measurement is based on risk adjusted performance with three types of measurement, Sharpe, Treynor and Jensen Index. When compared based on annual data, the performance of the JII portfolio is more resilient to unstable macroeconomic conditions [6].

Research with the title "Comparative Analysis of the Performance of Sharia Stock Indices with Conventional Stock Indexes for the Period of 2015-2017 (Case Studies on JII and LQ45)" concludes that changes in conventional stock prices tend to be more susceptible to changes in up or down significant compared to changes in sharia stock prices [7].

In research entitled "The Effective Solution Model of Sharia Market Stability" said that the coefficient of determination between the Islamic market and conventional markets is very low. The conventional market does not affect the sharia market, nor does the sharia market affect the conventional market [8].

In a study entitled "Market Dynamics Reality: Intensive Study of Conventional Sharia Educators" said that sharia stock fluctuations in ISSI were generally dominant following the fluctuations in conventional issuers. However, sharia stock fluctuations in JII are no longer dominant following conventional stock fluctuations [9].

In a study entitled "Effect of Macroeconomic Factors on the Composite Stock Price Index on the Indonesia Stock Exchange Period 2006-2015" it was said that macroeconomic factors (inflation, exchange rates and interest rates) together or simultaneously has a significant influence on the Composite Stock Price Index (CSPI) on the Indonesia Stock Exchange (IDX) [10].

In a study entitled "Influence of Inflation, Money Supply, Dollar Exchange Rate and GDP Growth on CSPI on the Indonesia Stock Exchange (BEI) " it was said that inflation, the amount of money in circulation didn't affect CSPI, while the dollar exchange rate and GDP growth have a significant positive effect on CSPI [11].

In a journal entitled "Analysis of Influence Inflation, Interest Rate, Exchange Rate and Gross Domestic Product Growth on the Composite Stock Price Index Case Study on Property Companies Listed on the Indonesia Stock Exchange" concluded that there was a significant positive influence on the level variable inflation and a significant negative effect on the variable exchange rate of the rupiah against the CSPI. Meanwhile, the variable GDP and interest rates there is no significant negative effect on the CSPI [12].

In a study entitled "Analysis of Pharmaceutical Sector Stock Performance on the Indonesia Stock Exchange (BEI) in 2012-2014" said that the current ratio(CR), Earning Per Share (EPS), and Net Profit Margin (NPM) has a significant effect on stock returns [13].

In a journal entitled "Influence of Inflation and Rupiah Exchange Rates on US Dollars on the Performance of Property and Real Estate Companies in Indonesia" said that inflation and exchange rates (exchange rates) had no significant effect against stock prices on property and real estate companies listed on the Indonesia Stock Exchange [14]. 
Research with the title "The Effect of the BI Rate, Inflation and Exchange Rates on the Composite Stock Price Index (CSPI)" concluded that the BI rate had a significant positive effect on the CSPI, the inflation value had a significant negative effect on the CSPI and the exchange rate not significant positive effect on CSPI. Simultaneously all of these variables have a significant positive effect on CSPI [15].

In the journal with the title "Influence of Cash Flow Againts Profitability and Stock Performance of Issuer Kompas 100 on the Stock Exchange Indonesia" that concluded the liquidity of cash and indicators flow of cash's operations that either effect the performance of the stock company. The good stock performance can described by the acquisition of the ratio of profit which increased and will affect that stock performance's companies directly [16].

In a journal entitled "Comparative Analysis of Manufacturing Sector Stock Performance between Food and Beverage Companies and Cosmetics on the Indonesia Stock Exchange in the 2014-2017 Period". Concluded that there was no significant difference in stock returns between food and beverage companies and cosmetics companies. While there are differences in sharpe indexes in the two sub-sectors of the company [1].

In a journal entitled "Analysis of the Influence of Inflation, SBI, Exchange Rates and Global Indexes on the Movement of Stock Price Indices on the Stock Exchange in the 20162018 Period". Concluded that the inflation variable, SBI, exchange rate, Dowjones Index, Nikkei 225 Index, Shanghai Index, together did not affect the CSPI, only the Hangseng Index influenced the CSPI [17].

The overall result of the research that showed above, actually between stock performance of conventional and sharia's index didn't have a significant difference. And also they showed coefficient of determination between the Islamic market and conventional markets is very low. The conventional market does not affect the sharia market, nor does the sharia market affect the conventional market. The result of the other variable about CSPI there are several variables that influence CSPI such as inflation, BI rate, exchange rates, interest rates, etc. In this research, the author develops the hypothesis below:

$\mathrm{H}_{1}$ : Stock Performance of Conventional Food and Beverages Companies towards Composite Stock Price Index

$\mathrm{H}_{2}$ : Stock Performance of Sharia Food and Beverages Companies towards Composite Stock Price Index

$\mathrm{H}_{3}$ : Stock Performance of Conventional and Sharia Food and Beverages Companies towards Composite Stock

Price Index

$\mathrm{H}_{4}$ : The Different between Stock Performance of Conventional and Sharia Food and Beverages Companies

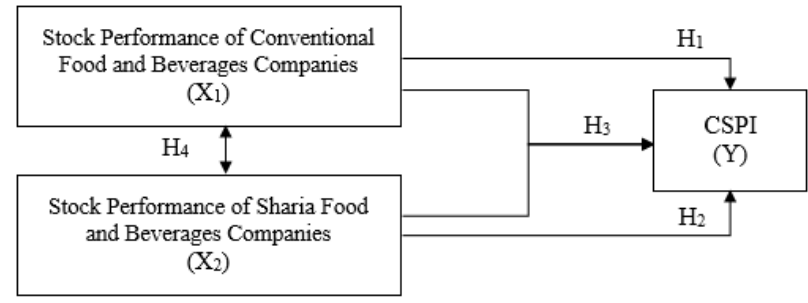

Fig.1. Conceptual Frameworks 


\section{Method}

\subsection{Variable Description and Indicator}

This type of research used a comparative descriptive method with a quantitative approach. The author will explain the research data using descriptive statistical analysis. While for the sample, author will only analyze sample with the criteria conventional food and beverage companies listed on the Indonesia Stock Exchange (BEI) and sharia food and beverages listed on the Indonesian Sharia Stock Index (ISSI) for a period of five years (20152019).

Research variables used in this study are stock performance of conventional and sharia food and beverages companies, and composite stock price index, there are the definition of those variables:

a. Stock performance of conventional and sharia food and beverages companies Assessment of the performance of conventional food \& beverages companies using the value of shares circulating in the capital market with the indicators include return and risk.

b. Stock performance of sharia food and beverages companies Assessment of the performance of sharia food \& beverages companies using the value of shares circulating in the capital market with the indicators include return and risk.

c. Composite stock price index

The composite stock price index (IHSG) is a reflection of general capital market activities with the indicator is that stock performance.

\subsection{Model of the Research}

This study used a research model in which the independent variables include the stock performance of conventional and sharia food and beverages companies. The dependent variable is composite stock price index. The empirical model of this study is formulates as follows:

$$
\widehat{Y}=a+b_{1} X_{1}+b_{2} X_{2}
$$

Description

$\widehat{Y} \quad$ : IHSG.

a : Constants

$b_{1}, b_{2} \quad$ : The regression coefficient for each variable.

$\mathrm{X}_{1} \quad$ : Stock performance of conventional food \& beverages companies.

$\mathrm{X}_{2} \quad$ : Stock performance of sharia food \& beverages companies.

\section{Result And Discussion}

There are several test that has been done in this research:

1) Descriptive Statistics 
From the data that has been collected is a summary of the performance data of conventional and sharia food and beverage companies and IHSG data, the results of descriptive statistical analysis are as follows:

Table 1. Descriptive Statistics

\begin{tabular}{lccc}
\hline \hline & $\begin{array}{c}\text { Conventional } \\
\text { Stock Performance }\end{array}$ & $\begin{array}{c}\text { Sharia } \\
\text { Stock Performance }\end{array}$ & IHSG \\
\hline \hline Mean & 0.001201 & 0.002042 & 0.003612 \\
Median & $2.95 \mathrm{E}-05$ & -0.000155 & 0.005644 \\
Maximum & 0.334340 & 0.164543 & 0.067793 \\
Minimum & -0.292746 & -0.119787 & -0.078325 \\
Std. Dev. & 0.091452 & 0.048341 & 0.031632 \\
Skewness & 0.452849 & 0.884784 & -0.563160 \\
Kurtosis & 7.000520 & 5.329907 & 3.137035 \\
Jarque-Bera & 42.06112 & 21.39960 & 3.218440 \\
Probability & 0.000000 & 0.000023 & 0.200044 \\
Sum & 0.072050 & 0.122535 & 0.216735 \\
Sum Sq. Dev. & 0.493449 & 0.137874 & 0.059034 \\
Observations & 60 & 60 & 60 \\
\hline
\end{tabular}

Based on the data that has been processed and analyzed, descriptive statistics from this study can be interpreted as follows:

a. Conventional Stock Performance

From the results of the test data it can be seen that the minimum value of conventional stock performance is -0.292746 and the maximum value is 0.334340 . Then it can be stated that in this research the sample size range of conventional stock performance between -0.292746 to 0.334340 with a mean value of 0.001201 on std. deviation of 0.091452 .

b. Sharia Stock Performance

From the results of the test data it can be seen that the minimum value of the performance of sharia shares is -0.119787 and the maximum value is 0.164543 . Then it can be stated that in this research the sample size range of conventional stock performance between -0.119787 to 0.164543 with a mean value of 0.002042 on std. deviation of 0.048341 .

2) Classical Assumption Test

Classic assumption test that is used to determine the feasibility of the regression model used in this study includes:

a. Normality Test

The results of normality test in this study indicate that the Jarque-Bera probability value is 0.421444 which is more than 0.05 , which means that the residual data in this study is normally distributed. 
b. Autocorrelation Test

The results of the autocorrelation test with the Breusch-Godfrey test show the ChiSquare (2) probability value of 0.5642 where the value is more than 0.05 , so that acceptance means there is no autocorrelation problem.

c. Multicolinearity Test

The multicollinearity test results show that the value of centered VIF in both conventional stock performance and sharia stock performance is 1.046946 which means less than 10 or it can be concluded that there is no multicollinearity problem in this study.

d. Heteroskedasticity Test

The results of the heteroscedasticity test show that the probability value of chisquare (2) is 0.1518 or more than 0.05 , so the regression model is free from heteroscedasticity.

3) Multiple Regression Analysis

Regression analysis on statistics is one of the methods used to determine the causal relationship between the variables. In this research the results of multiple linear regression analysis can be seen in table 2 below.

Table 2. Result of Multiple Regression Analysis

Dependent Variable: IHSG

Method: Least Squares

Sample: 2015M01 2019M12

Included observations: 60

\begin{tabular}{lrlrr}
\hline \hline \multicolumn{1}{c}{ Variable } & Coefficient & \multicolumn{1}{c}{ Std. Error } & t-Statistic & Prob. \\
\hline \multicolumn{1}{c}{ C } & 0.003144 & 0.003876 & 0.811107 & 0.4207 \\
Conventional's Stock Performance & -0.007756 & 0.043681 & -0.177570 & 0.8597 \\
$\quad$ Sharia's Stock Performance & 0.233911 & 0.082637 & 2.830585 & 0.0064 \\
\hline \hline R-squared & 0.131683 & Mean dependent var & 0.003612 \\
Adjusted R-squared & 0.101216 & S.D. dependent var & 0.031632 \\
S.E. of regression & 0.029988 & Akaike info criterion & -4.127302 \\
Sum squared resid & 0.051261 & Schwarz criterion & -4.022585 \\
Log likelihood & 126.8191 & Hannan-Quinn criter. & -4.086341 \\
F-statistic & 4.322113 & Durbin-Watson stat & 1.800856 \\
Prob(F-statistic) & 0.017879 & & \\
\hline \hline
\end{tabular}

Based on the above table, the regression equation can be arranged as follows:

$$
\mathrm{Y}=0.003144-0.007756 \mathrm{X}_{1}+0.233911 \mathrm{X}_{2}
$$

From the regression above, the research results are obtained:

1. The value of the constant coefficient of 0.003144 , meaning that if the conventional stock performance variable $\left(\mathrm{X}_{1}\right)$ and sharia stock performance $\left(\mathrm{X}_{2}\right)$ are considered constant then the IHSG (Y) will increase by 0.003144 . 
2. The coefficient value of conventional stock performance $\left(\mathrm{X}_{1}\right)$ is -0.007756 , meaning that if the variable $X_{1}$ increases by 1 unit, so IHSG (Y) decreases by 0.007756 assuming the other variables remain.

3. Coefficient of performance of sharia stocks $\left(\mathrm{X}_{2}\right)$ of 0.233911 , meaning that if the variable $\mathrm{X}_{2}$ increased by 1 unit, so IHSG (Y) increased by 0.233911 assuming other variables remain.

4) Independent Sample $T$ Test

After measure the return and risk, to see if there is a significant difference between the stock performance of conventional and sharia stocks, then used independent sample $t$ test to know the result. The table below is the result of the independent sample t test.

Table 3. Results of Independent sample t test

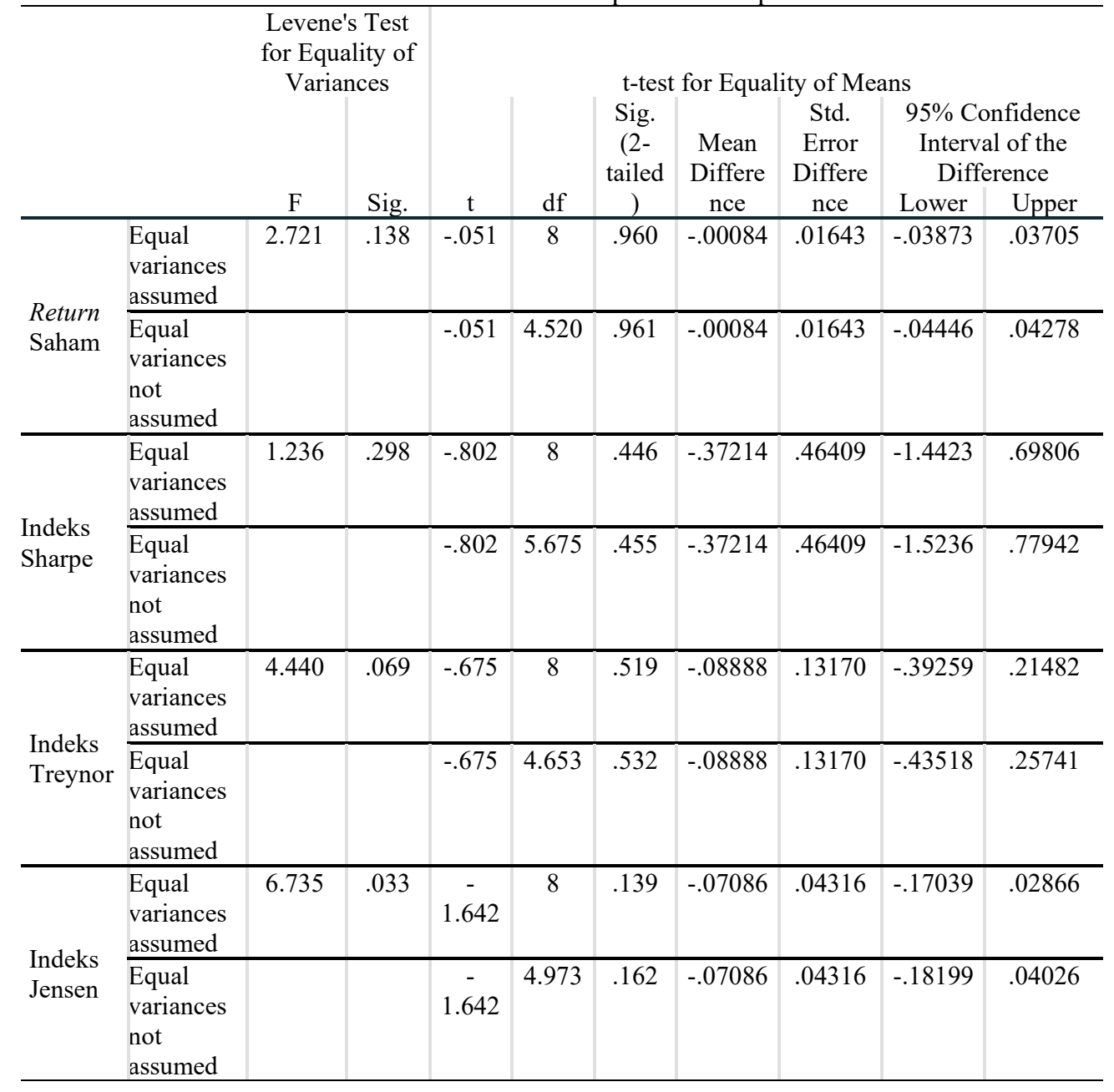

The results of the levene's test serve as a test whether the data in the research have the same variance or not. If the significant value is more than 0.01 then the data variance means 
equal, and if the significant value is less than 0.01 then the data variance means not the same. In this research, the stock return variable has a significant value of 0.138 or more than 0.01 which means the data variance is assumed to be the same. In the stock return variable, the significant value used for hypothesis testing is 0.960 because the data variance is the same.

Furthermore, the sharpe index variable has a significant value of 0.298 or more than 0.01 which means the data variance is assumed to be the same. For sharpe index variables, the significant value used for hypothesis testing is 0.446 because the data variance is the same. In the Treynor index variable has a significant value of 0.069 or more than 0.01 which means the data variance is assumed to be the same. For the Treynor index variable, the significant value used for hypothesis testing is 0.519 because the data variance is the same. And then, the jensen index variable has a significant value of 0.033 or more than 0.01 which means the data variance is assumed to be the same. For the jensen index variable, the significant value used for hypothesis testing is 0.139 because the data variance is the same.

After that compares a significant level with a significant value, if the value is significantly less than 0.01 , then $\mathrm{H}_{4}$ accepted, meanwhile if the value is significantly less than 0.01 then $\mathrm{H}_{4}$ rejected. In this research, significant values for each variable, 0960, 0446, 0519, and 0139 or greater than 0.01 so that $\mathrm{H}_{4}$ is received stating that there is no significant difference between the performance of stocks of companies of food and beverages conventional and sharia.

\section{Conclussion}

Based on the analysis that has been done through data and data processing on the stock performance of conventional and sharia food and beverages from 2015 to 2019 on the Composite Stock Price Index and comparison between the stock performance of conventional and sharia, the conclusions obtained from the analysis results are as follows:

1. In the results of multiple linear regression analysis, it can be seen that between conventional stock performance is inversely proportional or negatively affects IHSG, while the performance of sharia shares is directly proportional or positively influences on IHSG.

2. The stock performance of shariafood and beverage companies is better than conventional food and beverage companies based on stock returns and stock performance calculations through the risk adjusted performance method.

3. Hypothesis testing using the independent sample $t$ test states that based on the calculation of stock returns, sharpe index, treynor index and jensen index, there is no significant difference between the stock perfomance of conventional with sharia indexed food and beverages companies during the 2015-2019 period.

\section{References}

[1] C. F. Nuzula et al., "Analisis Perbandingan Kinerja Saham Sektor Manufaktur Antara Perusahaan Makanan Dan Minuman Dengan Kosmetik Di Bursa Efek Indonesia Periode 20142017," Natl. Conf. Manag. Bus., pp. 79-93, 2018.

[2] A. SHOLIHAH, "Perbandingan Kinerja Indeks Saham Syariah Dengan Indeks Konvensional Periode 2011-2016 (Studi Kasus Pada ISSI dan IHSG),” J. Ilmu Manaj., vol. 5, no. 3, pp. 1-9, 2017.

[3] A. A. Yudanto, "Performance Analysis of Sharia and Conventional Mutual Funds During 2008 and 2013 Crisis Periods," pp. 39-60. 
[4] I. D. Binangkit and E. Savitri, "Analisis Perbandingan Kinerja Saham-Saham Syariah dan Saham-Saham Konvensional Pada Portofolio Optimal dengan Pendekatan Single Index Model (Studi Kasus pada Bursa Efek Indonesia Tahun 2013-2015),” J. Tepak Manaj. Bisnis, vol. 8, no. 3, pp. 1-17, 2016.

[5] Y. Nurhayadi and N. Wijiharjono, "Strong Correlations of Sharia Market to Conventional Market: Evidence from Indonesia Stock Exchange," Int. J. Islam. Bus. Econ., vol. 1, no. 2, pp. 87-97, 2017.

[6] F. K. Mubarok, A. R. Darmawan, and Z. Luailiyah, "Optimalisasi Portofolio Nilai Saham: Studi Komparasi Kinerja Saham Syariah dan Nonsyariah,” Econ. J. Ekon. Islam, vol. 8, no. 2, p. 309, 2017.

[7] S. Febrianti, "Analisis Perbandingan Kinerja Indeks Saham Syariah Dengan Indeks Saham Konvensional Periode 2015-2017 (Studi Kasus Pada JII Dan LQ45)," Sendi_U, pp. 546-551, 2018.

[8] Y. Nurhayadi, Rito, and U. S. Al-Azizah, "Model Solusi Efektif Stabilitas Pasar Syariah,” AlUrban, vol. 2, no. 1, pp. 92-106, 2018.

[9] Y. Nurhayadi; Heriansyah, Daram; Susanti, Eva; Azizziah, "Realita Dinamika Pasar: Studi Intensif Distingsi Syariah Konvensional," Al-Urban, vol. 3, no. 2, pp. 109-202, 2019.

[10] R. Astuti, J. Lapian, P. Van Rate, J. Manajemen, E. Bisnis, and U. S. Ratulangi, "Pengaruh Faktor Makro Ekonomi Terhadap Indeks Harga Saham Gabungan (IHSG) Di Bursa Efek Indonesia (BEI) Periode 2006-2015," J. Berk. Ilm. Efisiensi, vol. 16, no. 2, pp. 399-406, 2016.

[11] I. Edi Kusuma and I. Badjra, "Pengaruh Inflasi, JUB, Nilai Kurs Dollar Dan Pertumbuhan GDP terhadap IHSG Di Bursa Efek Indonesia," E-Jurnal Manaj. Univ. Udayana, vol. 5, no. 3, pp. 1829-1858, 2016.

[12] Ni Wayan Sri Asih Masithah Akbar, "Analisis Pengaruh Inflasi, Suku Bunga, Nilai Tukar (Kurs) Dan Pertumbuhan Produk Domestik Bruto (PDB) Terhadap Indeks Harga Saham Gabungan (IHSG) Studi Kasus Pada Perusahaan Properti Yang Terdaftar Di Bursa Efek Indonesia," J. Manaj. dan Akunt., vol. 17, no. 1, pp. 43-52, 2016.

[13] F. Hidayat, J. Juwenah, and A. Dwi Astuti, "Analisis Kinerja Saham Sektor Farmasi Pada Bursa Efek Indonesia (BEI) Tahun 2012-2014,” J. Ris. Akunt. dan Keuang., vol. 4, no. 2, pp. 10871100, 2016.

[14] L. P. Putri, "Pengaruh Inflasi Dan Nilai Tukar Rupiah Atas Dollar AS Terhadap Kinerja Saham Perusahaan Property Dan Real Estate Di Indonesia," Ekon. J. Ilmu Ekon. dan Stud. Pembang., vol. 17, no. 1, pp. 46-55, 2016.

[15] N. Sunardi, L. Nurmillah, and R. Ula, "Pengaruh BI Rate, Inflasi Dan Kurs Terhadap Indeks Harga Saham Gabungan (IHSG)," J. Sekuritas, vol. 1, no. 2, pp. 27-41, 2017.

[16] A. K. P. B. Sitepu, Samsudin; Irwanto, "Pengaruh Arus Kas Terhadap Profitabilitas Dan Kinerja Saham Emiten Kompas 100 Di Bursa Efek,” J. Manaj. dan Organ., vol. VIII, no. 3 Desember 2017, pp. 236-249, 2017.

[17] O. A. Lusiana, "Analisis Pengaruh Inflasi, SBI, Kurs Dan Indeks Global Terhadap Pergerakan Indeks Harga Saham Di BEI Pada Periode 2016-2018,” vol. 8, no. 1, pp. 210-224, 2020. 